Monika Bartczak*

Nina Ogińska-Bulik**

* Departament of Psychology, The University of Sheffield

** Instytut Psychologii UŁ

\title{
Optymalne doświadczenia a pracoholizm. Kiedy zaangażowanie przeradza się w uzależnienie
}

\section{Wprowadzenie}

\subsection{Pojęcie optymalnych doświadczeń}

M. Csikszentmihalyi (1991) definiuje optymalne doświadczenia, inaczej przepływ (flow), jako stan umysłu, w którym jednostka odczuwa wewnętrzną motywację do wykonywania danej czynności, posiada poczucie kontroli nad sytuacją jak również doświadcza satysfakcji i przyjemności z jej wykonywania. Doświadczenie przepływu jest tak nagradzające, że jednostka chce wykonywać czynność wprowadzającą w ten stan dla samej przyjemności przeżywania flow. Badania przeprowadzone w USA i we Włoszech (C sik szentmihalyi, Csikszentmihalyi (red.), 1988; Massimini, Delle Fave, 2000) pozwoliły na rozwinięcie i potwierdzenie teorii optymalnych doświadczeń, według której do osiagnięcia stanu przepływu niezbędne są dwa warunki. Po pierwsze, stan równowagi pomiędzy postrzeganym przez jednostkę poziomem własnych umiejętności oraz postrzeganym poziomem trudności zadania. Po drugie, zarówno poziom umiejętności, jak i trudności zadania muszą być relatywnie wysokie. Inne kombinacje tych zmiennych prowadzą do mniej nagradzających doświadczeń. Czynności, w których poziom postrzeganych umiejętności przewyższa poziom trudności zadania, mogą wprowadzać w stan znudzenia, natomiast odwrotna kombinacja, czyli niski poziom postrzeganych umiejętności $\mathrm{w}$ połączeniu $\mathrm{z}$ wysokim poziomem trudności zadania, może wprowadzać w stan lęku lub niepokoju. Z kolei ostatnia kombinacja, gdzie zarówno poziom umiejętności i trudności zadania są niskie, może prowadzić do apatii. Poza tym stan flow charakteryzuje się: jasno określonym celem działań, otrzymywaniem informacji zwrotnych w trakcie wykonywania zadania, poczuciem całkowitej kontroli nad sytuacją oraz pełną koncentracją na danej czynności. W trakcie przepływu poczucie samoświadomości, jak również poczucie upływającego czasu mogą zostać zaburzone. Osoby doświadczające flow często 
czują jakby stawały się częścią większej całości, a czas upływa im bardzo szybko lub (wręcz przeciwnie) chwila wydaje się trwać wiecznie.

Badania prowadzone przez M. C siks ze nt mi halyi' e g o (1997) wykazały, że ludzie w bardzo podobny sposób opisują stan przepływu bez względu na rodzaj czynności, którą w danej chwili wykonują. Ponadto przepływ jest doświadczeniem uniwersalnym kulturowo, nie zanotowano również żadnych różnic ze względu na wiek, płeć oraz status społeczny. Ostatnie dwie dekady badań nad przepływem pokazały, że prawie każdy rodzaj ludzkiej działalności może być źródłem optymalnych doświadczeń. Badania przy użyciu metody pobierania próbek doświadczenia (ang. experience sampling method) wykazały, że przepływ najczęściej ma miejsce, gdy jednostka jest zaangażowana w wykonywanie ulubionych czynności, takich jak: słuchanie muzyki, gotowanie czy też granie w gry, jak również spędzanie czasu z przyjaciółmi, prowadzenie auta oraz aktywność zawodowa (Csikszentmihalyi, LaFevre, 1989). Zdaniem M. Csikszentmihalyi' eg o (2003) ok. 20\% Amerykanów doświadcza flow kilka razy dziennie, natomiast zaledwie 15\% twierdzi, że nigdy nie doświadczyło flow. Rozkład ten wydaje się dość uniwersalny, co zostało potwierdzone przez badanie przeprowadzone na populacji niemieckiej. 23\% Niemców doświadcza flow „często”, 40\% - „czasami”, 25\% - „rzadko”, a zaledwie $12 \%$ respondentów nigdy nie doświadczyło przepływu.

\subsection{Przeplyw w warunkach pracy}

Mimo iż większość ludzi deklaruje niższy poziom szczęścia $\mathrm{w}$ trakcie pracy, wcześniejsze badania wykazały, że przepływ najczęściej doświadczany jest podczas wykonywania czynności zawodowych (Csikszentmihalyi, 2003; Csikszentmihalyi, LaFevre, 1989). Wynik ten początkowo może wydawać się zaskakujący, kiedy jednak bliżej przeanalizujemy środowisko pracy, okazuje się, że stwarza ono dużo lepsze warunki umożliwiające doświadczanie przepływu niż większość czynności wykonywanych co dzień: jasno określone cele i zasady, ciagła informacja zwrotna oraz optymalny poziom umiejętności i trudności zadań. Tendencja ta jest prawdziwa dla wszystkich rodzajów pracy, od wysokich stanowisk menedżerskich po prace fizyczne. $47 \%$ czasu pracy pracownika fizycznego i $64 \%$ czasu pracy menedżera spełniają warunki niezbędne do osiagnięcia stanu flow (Csikszentmihalyi, La F e vre, 1989). A. B a k ker (2005, s. 27) zaadaptował konstrukt przepływu do aktywności związanych z pracą zawodową i zdefiniował flow jako stosunkowo krótkotrwałe doświadczenie szczytowe w pracy, charakteryzujące się trzema elementami: „wewnętrzną motywacją do pracy”, „zaabsorbowaniem” oraz „przyjemnością". Wewnętrzna motywacja do pracy jest definiowana jako potrzeba wypełniania obowiązków zawodowych w celu doświadczenia wewnętrznej przyjemności i satysfakcji. Zaabsorbowanie to stan całkowitego 
zaangażowania w wykonywaną czynność, który często może prowadzić do utraty zainteresowania pozostałymi aspektami otoczenia. Przyjemność z pracy to wynik zarówno emocjonalnej, jak i poznawczej oceny czynności wprowadzającej $\mathrm{w}$ stan przepływu. Badania nad kreatywnością przeprowadzone przez M. Csikszentmihalyi' ego (1996) ukazały, iż codzienna praktyka pracownika naukowego jest czynnością dużo bardziej wewnętrznie nagradzającą, niż sporadycznie doświadczane osiagnięcia naukowe. Sam proces rozwiązywania kreatywnych problemów, mimo iż wymaga przezwyciężenia bariery nowości i nieznajomości gruntu badawczego, jest aktywnością, podczas której doświadczany jest stan przepływu.

Wcześniejsze badania (B a k k e r, 2005; D e m e r o u ti, 2006) wykazały, że zasoby organizacyjne mogą być znaczącymi predyktorami przepływu doświadczanego $\mathrm{W}$ warunkach pracy. Badanie przeprowadzone wśród nauczycieli muzyki (B a k ker, 2005) potwierdziło, że nauczyciele doświadczający w pracy wysokiego poziomu autonomii, wsparcia społecznego, informacji zwrotnych oraz superwizji częściej doświadczali flow. Zgodnie z teorią poszerzającej i budującej funkcji pozytywnych emocji B. L. Fredrickson (2001) przepływ, jako przykład pozytywnych doświadczeń, może również prowadzić do wzrostu osobistych i organizacyjnych zasobów (Bakker i in., 2006). M. Csikszentmihalyi podkreśla też, że przepływ doświadczany w pracy ma znaczący wpływ na jakość życia, jak również kształtuje reakcję na stres (Csikszentmihalyi, 2003). Badanie przeprowadzone przez C. J. Fullagara i K. E. Kellow a y (2009) wskazuje na pozytywną korelację pomiędzy przepływem a pozytywnym nastrojem.

\subsection{Optymalne doświadczenia a pracoholizm}

Pojęcie pracoholizmu zostało wprowadzone do literatury przez W. O a te s a $(1971$, s. 11), który definiuje je jako ,[...] kompulsję lub niekontrolowana potrzebę nieustannej pracy", która może wywierać negatywny wpływ na zdrowie, poczucie szczęścia, relacje interpersonalne oraz funkcjonowanie społeczne. Jak zauważają L. H. W. M c Milla n i in. (2003), główne elementy charakteryzujące pracoholizm to nadmierna praca oraz obecność wewnętrznego przymusu do jej wykonywania. Pracoholicy spędzają wyjątkowo dużą ilość czasu w pracy, wkładając w nią znacznie więcej wysiłku niż jest to od nich wymagane. Ponadto posiadaja „obsesję” na jej punkcie, nieustannie myśląc o sprawach zawodowych również w czasie wolnym. Pracoholizm uważany jest za uzależnienie, czyli nadmierny i uporczywy wzorzec zachowania przynoszący jednostce szkodliwe konsekwencje, często porównywane do tych wynikających z alkoholizmu (P o r te r, 1996).

R. J. Burke i S. B. Matth i e s e n (2004) wykazali, że przepływ jest pozytywnie skorelowany z pozytywnym afektem, przyjemnością z pracy oraz 
efektywnością zawodową. Badanie wykazało również negatywną korelację pomiędzy przepływem a jednym $\mathrm{z}$ wymiarów pracoholizmu, przymusem pracy (ang. driveness; S p e n c e, R o b bin s, 1992). Natomiast w przeciwieństwie do zakładanej hipotezy nie zaobserwowano negatywnej korelacji pomiędzy flow a negatywnym afektem oraz dwoma wymiarami wypalenia zawodowego: wyczerpaniem emocjonalnym i cynizmem. Mimo iż w literaturze głównie przedstawia się przepływ jako pozytywny konstrukt przynoszący korzyści jednostce, należy również wspomnieć o potencjalnych negatywnych efektach związanych z przeżywaniem optymalnych doświadczeń, zwłaszcza w odniesieniu do sytuacji pracy - pracoholik, starając się ograniczać swoją aktywność tylko do pracy zawodowej, w konsekwencji zaniedbuje pozostałe aspekty swojego życia, w szczególności życie rodzinne (Sharma, Sharma, 2011). Podobnie nadmierne angażowanie się $\mathrm{w}$ czynności wprowadzające $\mathrm{w}$ stan przepływu może przynosić negatywne konsekwencje dla jednostki (Wesson, B oniwell, 2007). Częste doświadczanie flow w jednej określonej sferze życia, np. w pracy lub podczas wykonywania czynności, takich jak surfowanie po Internecie, moga negatywnie wpływać na ilość czasu poświęcanego innym aspektom życia. Jak zauważa I. B o n i w ell (2006), w promowaniu pozytywnych efektów optymalnych doświadczeń w społeczeństwie ważne jest nie tylko to, jak sprawić, by ludzie częściej je doświadczali, ale co najważniejsze, jak kontrolować stan flow, by umożliwić jednostce zachowanie równowagi między różnymi sferami życia.

\section{Cel i metoda badań}

Głównym celem podjętych badań było ustalenie zależności pomiędzy optymalnymi doświadczeniami a pracoholizmem. W odniesieniu do celu badań sformułowano szczegółowe pytania badawcze:

1. Czy pracoholizm występuje wśród pracowników naukowodydaktycznych i jeśli tak, to $\mathrm{w}$ jakim stopniu?

2. Czy pracownicy naukowo-dydaktyczni przeżywaja optymalne doświadczenia i jakie jest ich nasilenie?

3. Czy istnieje zależność pomiędzy zmiennymi socjodemograficznymi, takimi jak wiek, płeć, dyscyplina naukowa, a pracoholizmem oraz optymalnymi doświadczeniami?

4. Czy istnieje zależność między nasileniem optymalnych doświadczeń a pracoholizem?

5. W jakich sytuacjach pracoholicy (i niepracoholicy) doświadczają przepływu oraz jaka jest częstość występowania tego zjawiska?

W badaniach uczestniczyło 126 pracowników naukowo-dydaktycznych Uniwersytetu Łódzkiego oraz Politechniki Łódzkiej: 51,6\% stanowiły kobiety $(N=65)$, a $48,4 \%$ mężczyźni $(N=61)$. Średnia wieku badanej grupy wynosiła 
45,9 lat $(S D=11,3)$, najmłodsza osoba badana liczyła 28 lat, a najstarsza 76 lat. Większość badanych posiadała stopień doktora $(N=103 ; 81,7 \%), 18,3 \%$ grupy badanych było zatrudnionych na stanowisku profesora $(N=23)$. Średni okres zatrudnienia wynosił 19,3 lat $(S D=12,3)$. Ponad połowa badanych reprezentowała nauki humanistyczne $(57,1 \% ; N=72)$, a $42,9 \%$ - nauki ścisłe $(N=54)$. Badanie było przeprowadzone w okresie od grudnia 2008 do lutego 2009 r. Respondenci zostali poinformowani pocztą elektroniczną o możliwości wzięcia udziału w badaniu. Część badanych wypełniła papierową wersję kwestionariuszy $(N=67)$, natomiast pozostali wypełnili wersję elektroniczną $(N=59)$. Osoby badane zostały poinformowane, że udział w badaniu jest dobrowolny oraz o możliwości wycofania zgody w każdej chwili.

W badaniu zastosowano dwa narzędzia pomiaru: Kwestionariusz Pracoholizmu (WART; Goldberg, Hillier, 1979), polska adaptacja (Wojdyło, 2005), oraz Kwestionariusz do Badania Optymalnych Doświadczeń.

Kwestionariusz Pracoholizmu (WART), składający się z 25 stwierdzeń, mierzy poziom zagrożenia uzależnienia się od pracy. Respondenci proszeni są o zaznaczenie na skali 4-punktowej (od 1 - „prawie nigdy” do 4 - ,prawie zawsze"), jak trafnie twierdzenia opisują ich zachowania w pracy. Narzędzie mierzy 5 wymiarów pracoholizmu: obsesję pracy/kompulsję, emocjonalne pobudzenie/perfekcjonizm, przeciążenie praca, orientację na wynik oraz poczucie własnej wartości. Suma wyników poszczególnych wymiarów składa się na ogólny wskaźnik pracoholizmu. Wyniki możliwe do osiagnięcia znajdują się w przedziale od 25 do 100 pkt. Wyniki poniżej 56 pkt oznaczają brak uzależnienia od pracy, natomiast wyniki powyżej 56 pkt wskazują na występowanie przymusu pracy. Wyniki w zakresie 57-66 oznaczają uzależnienie w stopniu umiarkowanym, natomiast wyniki powyżej 66 pkt wskazują na wysoki stopień uzależnienia od pracy. Narzędzie to posiada zadowalające właściwości psychometryczne.

Kwestionariusz do Badania Optymalnych Doświadczeń składa się z dwóch części. Część pierwsza zawiera 21 twierdzeń mierzących poziom optymalnych doświadczeń, ocenianych na skali 6-punktowej (od 1 - ,zdecydowanie się nie zgadzam” do 6 - „zdecydowanie się zgadzam”). Rozpiętość wyników waha się od 21 do 126 pkt. Część druga zawiera pytania otwarte, w których respondenci proszeni są o wymienienie sytuacji, w których przeżywają optymalne doświadczenia, opisanie wybranej sytuacji oraz zaznaczenie na 6-punktowej skali (od $1-$, , ogóle nie” do 6 - „codziennie”), jak często doświadczali stanu przepływu w przeciagu ostatniego roku. Właściwości psychometryczne tego narzędzia są zadowalające ${ }^{1}$.

\footnotetext{
${ }^{1}$ Zarówno kwestionariusz, jak i informacje o jego właściwościach psychometrycznych uzyskano bezpośrednio od autorów polskiej wersji.
} 


\section{Wyniki badań}

\subsection{Sposób analizy danych}

Analiza danych została wykonana przy użyciu programu IBM SPSS Statistics 19 dla Windows. Średnie oraz odchylenia standardowe zostały obliczone dla wszystkich zmiennych. Test $t$ dla prób niezależnych został zastosowany do ustalenia różnic w poziomie pracoholizmu oraz jego wymiarów: 1) pomiędzy grupami o wysokich i niskich wynikach optymalnych doświadczeń, 2) w stosunku do zmiennych demograficznych: wiek, płeć, dyscyplina naukowa. Do ustalenia związku pomiędzy optymalnymi doświadczeniami a pracoholizmem i jego wymiarami wykorzystano współczynniki korelacji Pearsona. Następnym etapem analizy było zastosowanie testu $\chi^{2} \mathrm{w}$ celu ustalenia zależności między częstością doświadczania przepływu oraz sytuacjami, w jakich jest doświadczany a pracoholizmem.

\subsection{Statystyki opisowe}

W tab. 1 przedstawiono średnie i odchylenia standardowe dla optymalnych doświadczeń i pracoholizmu oraz jego wymiarów. Grupa badanych prezentuje średni poziom zagrożenia pracoholizmem $(M=57,74)$, aczkolwiek jedynie $34,1 \%$ badanych zostało zakwalifikowanych do grupy o niskim poziomie zagrożenia pracoholizmem, podczas gdy pozostali $(65,9 \%)$ zostali zaklasyfikowani do grupy o średnim $(43,7 \%)$ oraz wysokim $(22,2 \%)$ zagrożeniu uzależnieniem się od pracy.

Badani klasyfikują się do grupy o przeciętnym poziomie optymalnych doświadczeń $(M=99,57)$. Wyniki wysokie i niskie zostały ustalone w oparciu o średnią i $1 / 2$ odchylenia standardowego $(99,57 \pm 4,41)$. Wyniki wysokie znajdują się w przedziale od 104 do 126, wyniki przeciętne obejmują zakres od 96 do 103, zaś wyniki niskie - od 21 do 95.

T a b e la 1

Średnie i odchylenia standardowe dla optymalnych doświadczeń i pracoholizmu oraz jego wymiarów $(N=126)$

\begin{tabular}{|l|l|c|}
\hline Zmienna & $M$ & $S D$ \\
\hline Optymalne doświadczenia & 99,57 & 8,82 \\
Pracoholizm (wynik ogólny) & 57,74 & 10,11 \\
Obsesja/kompulsja & 14,51 & 3,64 \\
Emocjonalne pobudzenie/perfekcjonizm & 15,90 & 3,50 \\
Przeciążenie pracą & 10,80 & 2,68 \\
Orientacja na wynik & 7,25 & 1,53 \\
Poczucie własnej wartości & 9,24 & 1,96 \\
\hline
\end{tabular}

$\mathrm{O}$ b j a ś n i e n i a: $M$ - średnia, $S D$ - odchylenie standardowe.

Źró dło: opracowanie własne. 


\subsection{Zmienne socjodemograficzne a pracoholizm i optymalne doświadczenia}

Kolejnym etapem analizy było wykazanie zależności między zmiennymi socjodemograficznymi a wynikami pracoholizmu i jego wymiarów oraz optymalnych doświadczeń. Wyniki testu $t$ dla prób niezależnych, prezentujące różnice w poziomie pracoholizmu oraz optymalnych doświadczeń ze względu na zmienne demograficzne (wiek, płeć, dyscyplina naukowa), zostały zaprezentowane w tab. 2 . Na podstawie średniej $(M=45,93)$ zmienna wiek została podzielona na dwie kategorie: młodszych pracowników (do 46. roku życia) oraz starszych pracowników (powyżej 46. roku). Wyniki wykazały, że wiek nie różnicuje ogólnego poziomu pracoholizmu w badanej grupie. Różnice istotne statystycznie występują jedynie $\mathrm{w}$ dwóch wymiarach pracoholizmu: obsesja pracy/kompulsja oraz orientacja na wynik. Starsi pracownicy przejawiaja wyższy poziom obsesji pracy/kompulsji $\mathrm{w}$ porównaniu $\mathrm{z}$ grupą młodszych kolegów, podczas gdy młodsi pracownicy prezentują silniejszą orientację na wynik niż pracownicy starsi. Płeć oraz dyscyplina naukowa nie różnicują poziomu pracoholizmu ani żadnego $\mathrm{z}$ jego wymiarów, natomiast kobiety prezentują wyższy poziom optymalnych doświadczeń w porównaniu z mężczyznami.

\subsection{Zależności pomiędzy pracoholizmem i jego wymiarami a przepływem}

W tab. 3 zawarto średnie wartości pracoholizmu i jego wymiarów w grupie osób z niskim i wysokim wynikiem optymalnych doświadczeń. Test $t$ dla prób niezależnych wykazał różnicę istotną statystycznie między grupą o wysokich i niskich wynikach optymalnych doświadczeń w odniesieniu do jednego z wymiarów pracoholizmu - obsesja/kompulsja. Osoby badane należące do grupy o wysokich wynikach optymalnych doświadczeń uzyskały istotnie statystycznie wyższy wynik na skali obsesji/kompulsji w porównaniu z grupa o niskich wynikach. Wyniki w pozostałych wymiarach pracoholizmu oraz wynik ogólny pracoholizmu nie różnią się istotnie ze względu na poziom optymalnych doświadczeń. 


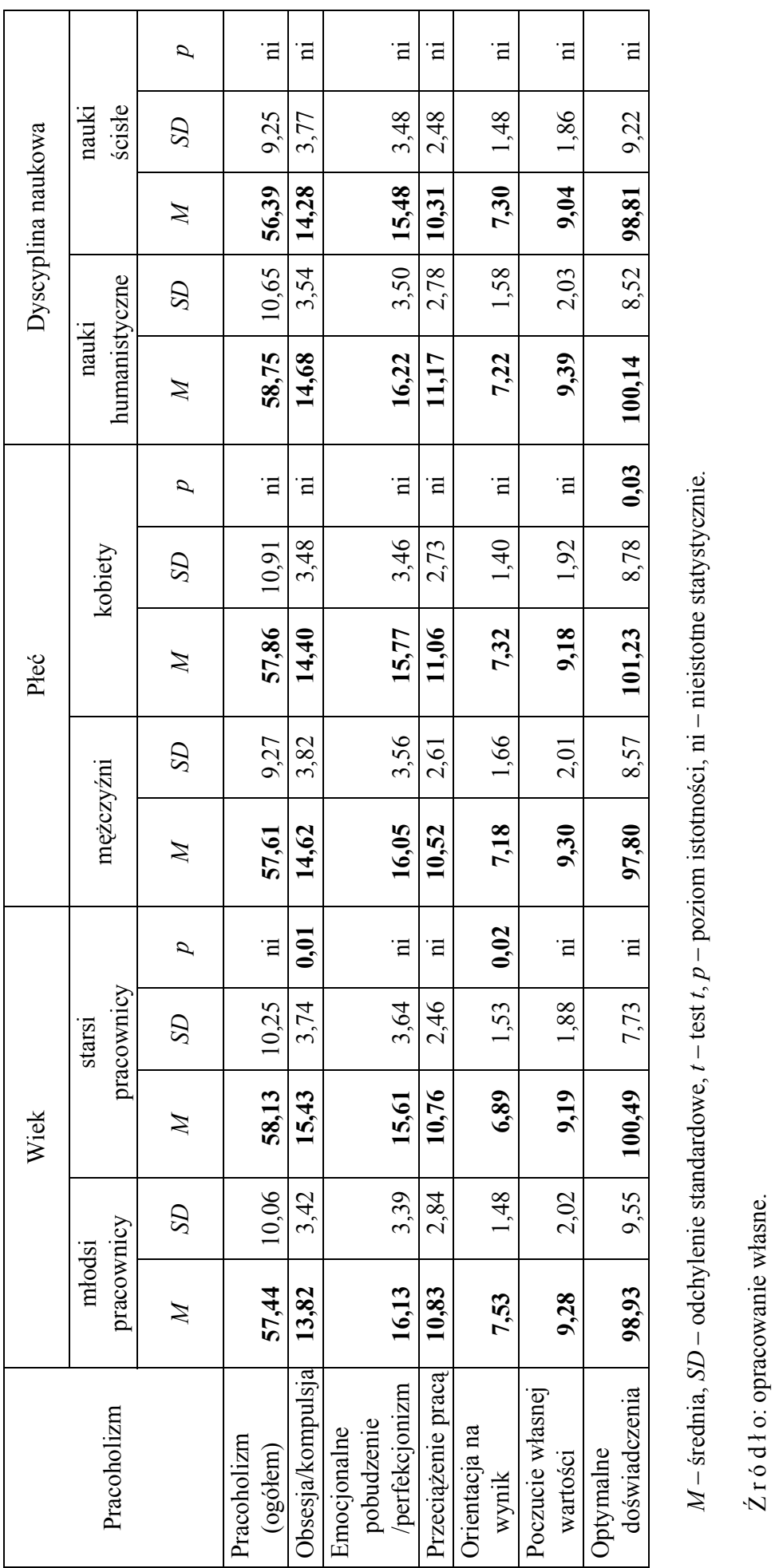


Średnie wartości pracoholizmu w grupie osób z niskim i wysokim wynikiem optymalnych doświadczeń $(N=81)$

\begin{tabular}{|c|c|c|c|c|c|c|}
\hline & \multicolumn{4}{|c|}{ Optymalne doświadczenia } & \multirow{3}{*}{$t$} & \multirow{3}{*}{$p$} \\
\hline & \multicolumn{2}{|c|}{$\begin{array}{l}\text { niski poziom } \\
\quad(N=38)\end{array}$} & \multicolumn{2}{|c|}{$\begin{array}{l}\text { Wysoki poziom } \\
\qquad(N=43)\end{array}$} & & \\
\hline & $M$ & $S D$ & $M$ & $S D$ & & \\
\hline Pracoholizm - wynik ogólny & 54,92 & 9,52 & 57,79 & 11,17 & $-1,25$ & ni \\
\hline Obsesja/kompulsja & 13,16 & 3,51 & 15,49 & 3,72 & $-2,18$ & 0,032 \\
\hline Emocjonalne pobudzenie/perfekcjonizm & 16,00 & 3,93 & 15,49 & 3,26 & $-0,63$ & ni \\
\hline Przeciążenie pracą & 9,66 & 2,77 & 10,60 & 2,54 & $-1,60$ & ni \\
\hline Orientacja na wynik & 7,26 & 1,54 & 7,42 & 1,40 & $-0,47$ & ni \\
\hline Poczucie własnej wartości & 8,87 & 1,56 & 9,30 & 2,03 & $-1,08$ & ni \\
\hline
\end{tabular}

$M$ - średnia, $S D$ - odchylenie standardowe, $t$ - test $t, p$ - poziom istotności, ni - nieistotne statystycznie.

Ź r ódło: opracowanie własne.

W następnym etapie analizy danych obliczono współczynniki korelacji Pearsona między pracoholizmem i jego wymiarami a przepływem. Wyniki przedstawione w tab. 4 wskazują na pozytywną, choć słabą, korelację między optymalnymi doświadczeniami a jednym z wymiarów pracoholizmu - obsesją/kompulsją.

T a b e la 4

Współczynnik korelacji Pearsona dla pracoholizmu oraz jego wymiarów i optymalnych doświadczeń

\begin{tabular}{|l|c|}
\hline \multicolumn{1}{|c|}{ Pracoholizm } & $\begin{array}{c}\text { Optymalne } \\
\text { doświadczenia }\end{array}$ \\
\hline Pracoholizm (ogółem) & 0,132 \\
\hline Obsesja/kompulsja & $\mathbf{0 , 2 3 7 *}$ \\
\hline Emocjonalne pobudzenie/perfekcjonizm & $-0,002$ \\
\hline Przeciążenie pracą & 0,144 \\
\hline Orientacja na wynik & 0,014 \\
\hline Poczucie własnej wartości & 0,117 \\
\hline
\end{tabular}

$* p<0,01$.

Ź r ódło: opracowanie własne. 


\subsection{Sytuacje, w jakich występuje przepływ oraz częstość jego doświadcza- nia w grupie pracoholików i niepracoholików}

$\mathrm{Na}$ dalszym etapie badań poddano analizie odpowiedzi respondentów na pytanie otwarte dotyczące sytuacji, w których przeżywają optymalne doświadczenia oraz jak często doświadczali stanu przepływu w przeciągu ostatniego roku (od 1 - „W ogóle nie” do 6 - „codziennie”). Z powodu znacznych braków $\mathrm{w}$ odpowiedziach, $\mathrm{w}$ analizie zostało uwzględnionych 70 respondentów. Odpowiedzi badanych na pytanie pierwsze zostały zaklasyfikowane do 1 z 3 kategorii: doświadczanie flow: 1) tylko w pracy naukowo-dydaktycznej, 2) tylko $\mathrm{w}$ czasie wolnym, 3) zarówno w trakcie pracy naukowo-dydaktycznej, jak i w czasie wolnym. Na rys. 1 przedstawiono rozkład poszczególnych kategorii dla grupy pracoholików $(N=35)$ i niepracoholików $(N=35)$. W celu ustalenia różnic między pracoholikami i niepracoholikami przeprowadzono test $\chi^{2}$. Wyniki testu wykazały różnicę istotną statystycznie między tymi dwiema grupami $\left(\chi^{2}(2)=7,097 ; p=0,029\right)$. Pracoholicy $(65,7 \%)$ częściej niż niepracoholicy $(34,3 \%)$ doświadczają przepływu tylko w warunkach pracy zawodowej. Z kolei niepracoholicy $(48,6 \%)$ znacznie częściej od pracoholików (22,9\%) doświadczają przepływu zarówno w pracy, jak i w czasie wolnym. Najmniej liczną kategorią dla obu grup było doświadczanie przepływu jedynie w czasie wolnym (pracoholicy $-11,4 \%$, niepracoholicy $-17,1 \%$ ).

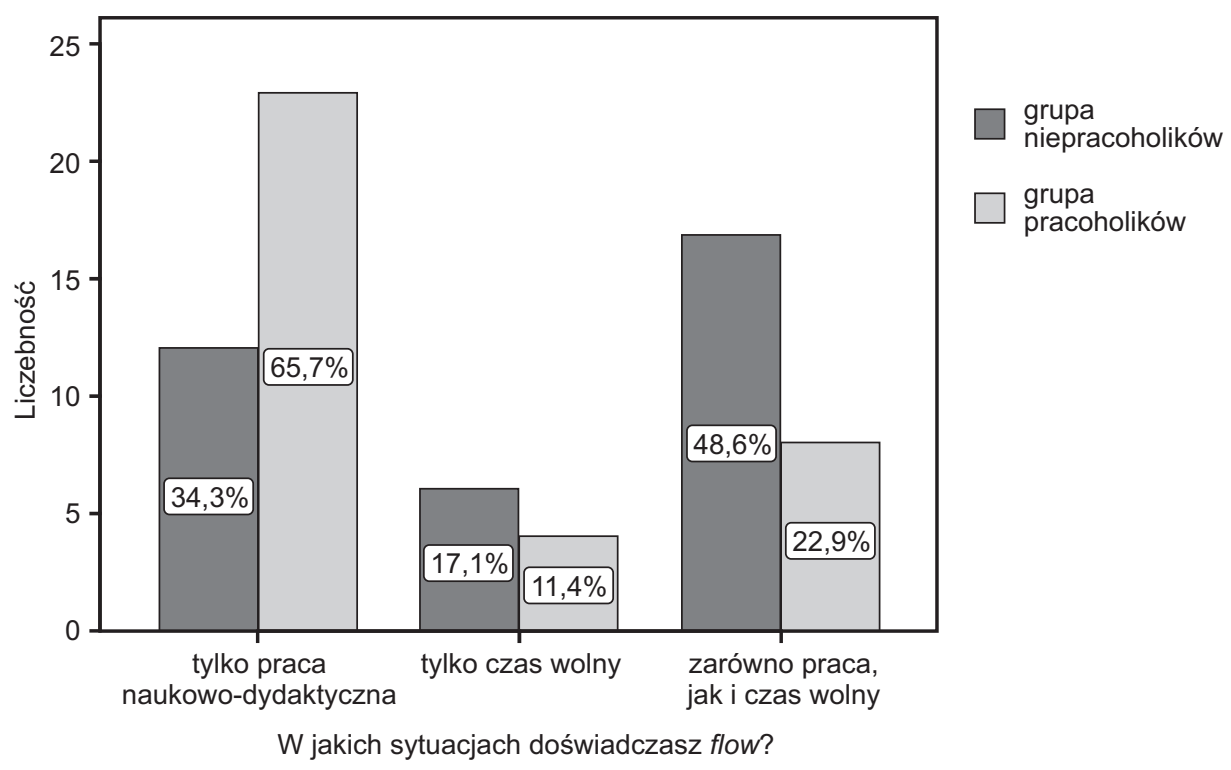

Rys. 1. Rozkład kategorii sytuacji, w których respondenci doświadczali przepływu w grupie pracoholików i niepracoholików $(N=70)$

Źr ó d ło: opracowanie własne. 


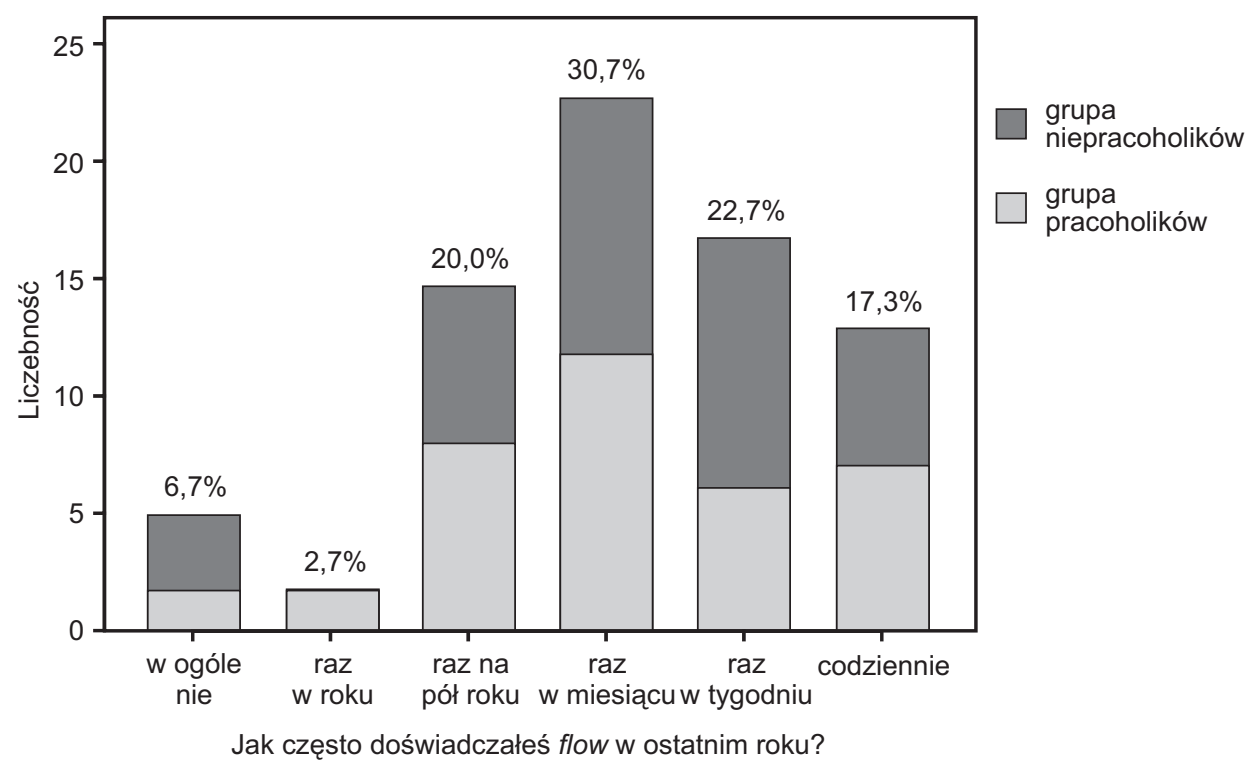

Rys. 2. Rozkład odpowiedzi na pytanie dotyczące częstości doświadczania przepływu w grupie pracoholików i niepracoholików (w \%; $N=75$ )

Źr ódło: opracowanie własne.

Na rys. 2 zaprezentowano rozkład odpowiedzi na pytanie dotyczące częstości doświadczania przepływu dla obu grup. Z powodu małej liczebności komórek do analizy danych zastosowano test ilorazu wiarygodności. Analiza wykazała brak istotnych różnic między pracoholikami i niepracoholikami ( $L$-test ilorazu wiarygodności $\left.L \chi^{2}(5)=4,64 ; p=0,461\right)$. W badanej grupie ok. 30\% doświadcza przepływu raz w miesiącu, nieco ponad $22 \%$ - raz w tygodniu, $20 \%$ - raz na pół roku. Przepływu codziennie doświadcza ok. 17\%, natomiast niecałe 3\% nie częściej niż raz w roku. Zaledwie 6,7\% respondentów zadeklarowało, że w przeciagu ostatniego roku nie doświadczyli stanu przepływu.

\section{Podsumowanie}

Niespełna $66 \%$ osób badanych zostało zakwalifikowanych do grupy o średnim lub wysokim nasileniu pracoholizmu. Wyniki przeprowadzonej analizy ujawniły brak istotnych zależności pomiędzy zmiennymi demograficznymi a pracoholizmem. Istotne różnice zostały jedynie zaobserwowane pomiędzy dwoma wymiarami pracoholizmu: obsesja/kompulsją oraz orientacją na wynik a wiekiem. Starsi pracownicy przejawiają wyższy poziom obsesji/kompulsji w porównaniu z grupą młodszych kolegów, podczas gdy młodsi 
pracownicy posiadają silniejszą orientację na wynik niż pracownicy starsi. Analiza wykazała, że kobiety prezentują wyższy poziom optymalnych doświadczeń niż mężczyźni, podczas gdy wcześniejsze badania (B urke, Matth i e s e n, 2004, 2009; C s i s z e n t mi ha ly i, 1997) sugerują brak istotnych różnic międzypłciowych.

W przeciagu roku większość badanych chociaż raz doświadczyła stanu przepływu $(93,3 \%)$. Wyniki wykazały brak istotnych różnic w częstości doświadczania przepływu między pracoholikami i niepracoholikami. Kiedy jednak analizie zostały poddane sytuacje, w których respondenci przeżywali flow, różnice między grupą pracoholików i niepracoholików okazały się istotne. Pracoholicy znacznie częściej niż niepracoholicy doświadczają przepływu tylko w warunkach pracy zawodowej, podczas gdy niepracoholicy w większości przeżywają flow zarówno w pracy, jak i w czasie wolnym. Czynnikiem różnicującym te dwie grupy nie jest więc częstość doświadczania flow czy też jego poziom, ale sytuacje, w których jest ono przeżywane. Niepracoholicy, w przeciwieństwie do pracoholików, potrafią utrzymać równowage między życiem osobistym i zawodowym. Życie poza pracą jest dla nich równie cennym źródłem pozytywnych doświadczeń. Natomiast nadmierne angażowanie się $\mathrm{w}$ pracę powoduje, że pracoholicy nie poświęcają wystarczającej uwagi życiu prywatnemu. W związku z tym ograniczają zakres sytuacji, w których doświadczają flow, głównie do aktywności zawodowej. Ponadto analiza wykazała pozytywną choć słabą - korelację pomiędzy jednym z czynników pracoholizmu: obsesją pracy/kompulsją oraz przepływem. Czynnikiem łączącym te dwa zjawiska jest więc ich obsesyjno-kompulsywny charakter. Powyższe wyniki wskazują na potencjalne negatywne efekty nadmiernego angażowania się $\mathrm{w}$ stan przepływu w grupie pracoholików.

Zaprezentowane rezultaty badań, wskazujące na zależność między analizowanymi zmiennymi, powinno się traktować $\mathrm{z}$ pewną ostrożnością. Należy zwrócić uwagę na przekrojowy charakter badań, który nie pozwala na ustalenie związku przyczynowo-skutkowego. Ponadto, z powodu braków w odpowiedziach, część analiz została przeprowadzona na znacznie mniejszej liczbie badanych. Należy również pamiętać o ograniczonych możliwościach uogólnienia wyników na szerszą populację z powodu wielkości oraz słabej reprezentatywności badanej grupy.

\section{Wnioski}

Nadszedł moment, by udzielić odpowiedzi na pytanie postawione $\mathrm{w}$ tytule artykułu. Kiedy pasja przeradza się w uzależnienie? Wyniki powyższych badań sugerują, że czynność może stać się obiektem uzależnienia, w momencie gdy przesłania pozostałe sfery życia. Jednostka zaczyna inwestować swoje zasoby 
(np. czas, uwagę, energię) w czynności związane z daną aktywnością tutaj pracą zawodową. Teoria zachowania zasobów (Ho b fo 11, 2002) thumaczy, dlaczego nadmierne angażowanie się w jedną czynność może pociągać za sobą negatywne efekty. Zdaniem S. E. Hobfolla, inwestowanie zasobów w jedną sferę życia prowadzi do uszczuplenia zasobów na inwestycje w pozostałe aktywności jednostki. Pracoholicy, angażując swoje zasoby głównie w czynności związane z praca, nie potrafią zachować balansu pomiędzy życiem prywatnym a zawodowym. Mimo iż stan flow jest uważany za zjawisko pozytywne, często nazywane kwintesencją ludzkiego życia (Csikszentmihalyi, 1991), należy podkreślić, iż przeżywanie flow tylko w jednej sferze życia może nieść ze sobą negatywne konsekwecje. Stymulowanie doświadczania flow u pracoholików poza sferą aktywności zawodowej może do pewnego stopnia przyciągnąc ich uwagę oraz inwestycje zasobów w pozostałe aspekty życia i dzięki temu przyczynić się do przywrócenia balansu między poszczególnymi sferami życia.

\section{Bibliografia}

B a k k r A. (2005), Flow among music teachers and their students: The crossover of peak experiences, „Journal of Vocational Behavior”, 66, 26-44.

B a kke r A., L lorens S., S a l a n ova M. (2006), Flow at work: Evidence for an upward spiral of personal and organizational resources, „Journal of Happiness Studies”, 7, 1-22.

B o n iw e 11 I. (2006), Positive psychology in a nutshell: A balanced introduction to the science of optimal functioning, PWBC, London.

B urke R. J., Matthi es en S. B. (2004), Correlates of Flow at Work among Norwegian Journalists, ,Journal of Transational Management”, 10 (2), 49-58.

Burke R. J., Matthi esen S. B. (2009), Workaholism among Norwegian Journalists: Gender Differences, „Equal Opportunities International”, 28 (26), 452-464.

Csikszentmihalyi M. (1991), Flow: The psychology of optimal experience, Harper \& Row, New York.

Csikszentmihalyi M. (1996), Creativity: Flow and the Psychology of Discovery and Invention, Harper Perennial, New York.

C s i ks ze n t m i h ly i M. (1997), Finding flow: The psychology of engagement in everyday life, Harper \& Row, New York.

C s i k s z e n t m i h l y i M. (2003), Good business, Viking, New York.

Csikszentmihalyi M., Csikszentmihalyi I. (eds.) (1988), Optimal experience: Psychological studies of flow in consciousness, Cambridge University Press, New York.

Csikszentmihalyi M., LaFevre J. (1989), Optimal experience in work and leisure, „Journal of Personality and Social Psychology”, 56, 815-822.

D e m e r o ut i E. (2006), Job characteristics, flow, and performance: The moderating role of conscientiousness, ,Journal of Occupational Health Psychology”, 11, 266-280.

Fredrickson B. L. (2001), The Role of Positive Emotions in Positive Psychology: The broaden-and-build theory of positive emotions, „American Psychologist”, 56, 218-226.

F u 11 a g a r C. J., K e 11 o w y K. E. (2009), 'Flow' at work: An experience sampling approach, „Journal of Occupational and Organizational Psychology”, 82, 595-615. 
Goldberg D. P., Hilli er V. F. (1979), A scaled version of the General Health Questionnaire, „Psychological Medicine”, 9, 139-145.

$\mathrm{Ho}$ b foll S. E. (2002), Social and psychological resources and adaptation, Review of General Psychology", 6, 307-324.

Mass i min i F., D e 11 e F a v e A. (2000), Individual development in a bio-cultural perspective, ,American Psychologist”, 55 (1), 24-33.

M c Milla n L. H. W., O' D ri s c oll M. P., B u rke R. J. (2003), Workaholism: A review of theory, research, and future directions, [w:] C. L. C o o p e r, I. T. R o b e r t s o n (eds.), International review of industrial and organizational psychology, 18, Wiley, New York, 167-189.

O a t e s W. (1971), Confessions of a workaholic, World, New York.

P orter G. (1996), Organizational Impact of Workaholism: Suggestions for Researching the Negative Outcomes of Excessive Work, „Journal of Occupational Health Psychology”, 1, 7084.

Sharma P., Sharma J. (2011), Work-Addiction: A Poison by Slow Motion, „Journal of Educational and Behavioral Statistics", 2 (3), 86-91.

Spence J. T., Robbins A. S. (1992), 'Workaholism': definition, measurement, and preliminary results, „Journal of Personality Assessment”, 58, 160-178.

W e s s o n K., B o n iwe 11 I. (2007), Flow theory - its application to coaching psychology, „International Coaching Psychology Review”, 2 (1), 33-43.

W ojd yło K. (2005), Kwestionariusz Pracoholizmu (WART) - adaptacja narzędzia i wstęnna analiza wlasności psychometrycznych, „Nowiny Psychologiczne”, 4, 71-84.

Monika Bartczak, Nina Ogińska-Bulik

\section{Optimal experiences and workaholism. When engagement turns into addiction}

The aim of this study was to establish the relationship between optimal experiences and workaholism. The study was conducted on a group of academic workers recruited from The University of Łódź and Technical University of Łódź $(N=126)$. Polish adaptation of WART and The Questionnaire Measuring Optimal Experiences were used to measure workaholism and flow, respectively. The vast majority of participants have experienced flow at least once or more within a year (93.3\%). The analysis revealed the lack of significant differences between groups of workaholics and nonworkaholics in the levels of flow and in the frequency of experiencing flow. However, the factor that distinguishes these two groups is the range of situations in which they experience flow. Thus, workaholics experience flow mainly in work settings, while nonworkaholics experience flow both at work and in their free time. Moreover, the analysis revealed positive but weak correlation between one of the workaholism dimension: obsession/compulsion and flow. Therefore, the element that links those two phenomena is their obsessive-compulsive character. The article draws attention to potential negative consequences related to over engagement in flow activities.

Keywords: workaholism, optimal experiences, academic workers (pracoholizm, optymalne doświadczenia, pracownicy naukowi). 